\title{
Wu Hung: Remaking Beijing. Tiananmen Square and The Creation of a Political Space.
}

Chicago: The University of Chicago Press, 2005, 272 pp.

\section{Emmanuel Lincot}

\section{OpenEdition}

\section{Journals}

Édition électronique

URL : http://journals.openedition.org/chinaperspectives/1056

DOI : 10.4000/chinaperspectives.1056

ISSN : 1996-4617

\section{Éditeur}

Centre d'étude français sur la Chine contemporaine

Édition imprimée

Date de publication : 1 octobre 2006

ISSN : 2070-3449

\section{Référence électronique}

Emmanuel Lincot, «Wu Hung: Remaking Beijing. Tiananmen Square and The Creation of a Political Space. », China Perspectives [En ligne], 67 | september-october 2006, mis en ligne le 01 juin 2007, consulté le 24 septembre 2020. URL : http://journals.openedition.org/chinaperspectives/1056 ; DOI : https://doi.org/10.4000/chinaperspectives.1056

Ce document a été généré automatiquement le 24 septembre 2020

(c) All rights reserved 


\section{Wu Hung: Remaking Beijing. Tiananmen Square and The Creation of a Political Space.}

Chicago: The University of Chicago Press, 2005, 272 pp.

\section{Emmanuel Lincot}

\section{NOTE DE L'ÉDITEUR}

Translated from the French original by Michael Black

$1 \mathrm{Wu}$ Hung has made a major contribution to the understanding of the history and anthropology of contemporary Chinese memory. His works builds on the specificities of the University of Chicago, which combines theoretical thought with studies in the field. An art historian by training, and the author of ten books, Wu Hung is looked on as a pioneer in the field of American sinology for his analyses of Chinese culture from the most ancient to the most recent periods through a systematic comparison of texts and visual signs; the daring of this approach sometimes brings to mind, in contemporary French historiography, Georges Didi-Huberman. To quote Wu Hung: "This book is not written for a particular academic field, but is located in a network of disciplines including art history, the history of architecture, modern chinese history, urban studies, cultural studies and autobiography. In fact, one of my purposes in writing this book is to forge this interdisciplinary network" (p. 10). In approaching Tiananmen and the metamorphoses of the site through more than a century of the history of Beijing and of China, Wu Hung opens up new epistemological and pragmatic perspectives. Displacing the temporal totality towards the present and towards action, Wu Hung shows, based on a study of this site in its particularity, that the past is not closed, that it is not a dead thing to be mummified in a museum, but on the contrary that it still remains open to new meanings. 
2 The personal involvement of the author, whose intimate style and the value of whose personal experience will be appreciated, makes possible a double reading which draws on the manner of Roland Barthes in The Darkroom. Beyond the emotion which is revealed on reading the pages where the author makes a moving and painful confession of his activities as a young intellectual during the Cultural Revolution-which, as the work of Michel Bonnin has shown, only added to the countless trials and tribulations shared by a whole generation-we have a moving story of the status of an academic who chooses to go into exile-which brings him closer to the condition of Edward Saïd. Wu Hung's book is not only biographical, however. He invites us on a constant return journey between history and memory, between the personal and the collective, by interrogating a complex of layered temporalities which seems exemplary in more ways than one.

3 Basing himself on hitherto unpublished iconographic documents, Wu Hung focuses on the architectural origins of Tiananmen, which was decided on and planned by Mao Zedong, whose official portrait and mausoleum stamp their mark on the space. The spectacular transformations of Tiananmen, which are visible in the erection of buildings with strong symbolic connotations (The People's Congress, The Museum of History), form part of a political logic. Inspired by Soviet models, they are the most visible signs of a performative writing of Utopia. Built in less than a year, as were the Palace of Fine Arts, the Military Museum and the Beijing Railway Station, they were the glory of the regime while at the same time concealing its incompetence. The year 1959, when they were completed, was in fact the beginning of a long and criminal period of famine in the countryside, as a result of the Great Leap Forward. The simultaneous erection of these monuments is thus a reminder of the principle of contradiction inherent in the workings of the communist system.

4 In Wu Hung's book, urban maps, portraits of official architects and of leaders accompany and intersect with the no less vivid memories of the images of angry dissidents and artists taking possession of an extremely ambivalent space. For Tiananmen Square has been emblematic of China's history all through the twentieth century. A symbol of the durability of power through time, it became the scene of the great gatherings and collective tragedies, from the demonstration on May 4th 1919, which set China on the path of militant modernity, to the fearsome image, seventy years later, of the stoic unknown demonstrator, halting the advance of the tanks. Wu Hung's openness to the theme of memory in the field of art and the parallel he establishes with history lead him to distinguish two forms of the use of time: one which increases the standing of places and the other temporal combinations. This equivocation, which seems likely to increase in the context of the de-Maoisation of Chinese society, is perceptible in a city such as Beijing, which seeks to culturalise its places in order either to make them more liveable, or to invest them with an aura, in Walter Benjamin's meaning of the word, by conferring on them an artificial historic dignity, and thus playing on different stratified temporalities. The example discussed by Wu Hung, the construction by the French architect Paul Andreu of the new Beijing Opera, a stone's throw from Zhongnanhai and Tiananmen Square, is highly evocative in this respect.

5 The last form of the usage of time is time without trace, which falls within the province of simple loss, and which $\mathrm{Wu}$ Hung places in the realm of the oral-by collecting 
personal external accounts-and of oblique artistic production (performances and photographs) which seems to have experienced an entirely new energy since 1989.

Memory, in thus investing the spatial transformations of the site, also sets up breaks in time, which open onto new temporalities. Thus, the sudden appearance of the first Western public clocks, in the immediate perimeter of Tiananmen, drastically changed the relationship between the Chinese and their traditional society. The digital screen clocks counting down the retrocession of Hong Kong and then of Macau took over the symbolic value and the distribution of time: "With its exaggerated size and appearance of a legal certificate, the Clock reasserted the schedule for Hong Kong's return and expressed the determination to realise this goal by any means, including military intervention. Located in Tiananmen Square, it sent out signals from the heart of the Communist political machine" (p. 163). The socio-historical aspects resulting from economic, political, and even religious experiences (such as the replacement of Taoist gongs by the sound of church bells) could have been further explored by the author. Similarly a comparative parallel between Wu Hung's problematics and work as important as that carried out, albeit in different historical and geographical contexts, by Marc Augé, Eric Michaud, Alain Corbin, Michel de Certeau and Louis Marin, on the relationship between the symbolics of place and those of power, would have given greater depth to this comprehensive reflection. These last observations apart, Wu Hung's book is essential in its aim, and one can only hope for translations-particularly into Chinese and French-which will give it a wider audience. 